\title{
Studies on Blood and Plasma Catalase
}

\author{
The 4th Report \\ The Blood and Plasma Catalase Content in \\ Various Experimental Anemias \\ By \\ Syoiti Yamagata and Sukehiko Seino \\ (山形敞一) (清野被监) \\ (From the Medical Clinic of Prof. T. Kurokawa, \\ Tohoku University, Sendai) \\ (Received for publication, July 30, 1952)
}

From our former report ${ }^{11}$, it is presumed that the blood catalase content changes in the close connection with erythrocytes and hemoglobin, but the plasma catalase content is influenced not only by the hemopoietic function, but also by the hemolysis in a living body and the hemoclastic function of the spleen.

Therefore, we made an attempt to measure the blood and plasma catalase content in various experimental anemias to make clear its significance.

\section{EXPERIMENTAL}

\section{Results}

1. Anemia caused by artificial bleeding

In our former report ${ }^{2)}$ we confirmed that there is no evident diurnal variation of the blood and plasma catalase content as the control test of normal rabbits.

In order to make an artificial anemia, $10 \mathrm{cc}$. of the blood was taken out from rabbits for 7 days by heart puncture. Data presented in Table I show that the blood catalase content decreases in company with erythrocytes and hemoglobin in anemia caused by artificial bleeding, but the recovery of the blood catalase content after stopping the bleeding precedes that of erythrocytes and hemoglobin, while the variation of the plasma catalase content is not remarkable. Moreover, the catalase index, hemoglobin-catalase index and plasma-blood catalase ratio tend to increase temporarily.

2. Anemia caused by phenylhydrazine

After subcutaneous injection of phenylhydrazine hydrochloride in doses of $2 \mathrm{cc}$. per $\mathrm{kg}$. body weight of $1 \%$ solution for 3 days, the blood 
TABLE I

Blood and Plasma Catalase Content by Artificial Bleeding

\begin{tabular}{|c|c|c|c|c|c|c|c|c|c|c|c|c|c|c|}
\hline & No. & $\begin{array}{c}\text { Before } \\
\text { bleed- } \\
\text { ing }\end{array}$ & $\begin{array}{l}\text { lst } \\
\text { day } \\
\text { after } \\
\text { bleed- } \\
\text { ing }\end{array}$ & $\begin{array}{c}\text { 2nd } \\
" \\
"\end{array}$ & $\begin{array}{c}\text { 3rd } \\
" \\
"\end{array}$ & $\begin{array}{c}\text { 4th } \\
" \\
" \\
",\end{array}$ & $\begin{array}{c}5 \text { th } \\
" \\
" \\
"\end{array}$ & $\begin{array}{c}\text { 6th } \\
" \\
" \\
"\end{array}$ & $\begin{array}{c}7 \text { th } \\
" \\
" \\
"\end{array}$ & $\begin{array}{c}\text { 8th } \\
" \\
" \\
"\end{array}$ & $\begin{array}{c}9 \text { th } \\
" \\
"\end{array}$ & $\begin{array}{c}11 \text { th } \\
" \\
" \\
"\end{array}$ & $\begin{array}{c}13 \text { th } \\
" \\
"\end{array}$ & $\begin{array}{c}15 \text { th } \\
" \\
"\end{array}$ \\
\hline & $\begin{array}{l}1 \\
2\end{array}$ & $\begin{array}{l}614 \\
518\end{array}$ & 4 & $\begin{array}{l}407 \\
411\end{array}$ & $\begin{array}{l}336 \\
330\end{array}$ & $\begin{array}{l}348 \\
342\end{array}$ & $\begin{array}{l}471 \\
312\end{array}$ & $\begin{array}{l}445 \\
242\end{array}$ & $\begin{array}{l}443 \\
287\end{array}$ & $\begin{array}{l}420 \\
303\end{array}$ & $\begin{array}{l}420 \\
336\end{array}$ & $\begin{array}{l}481 \\
346\end{array}$ & $\begin{array}{l}534 \\
486\end{array}$ & $\begin{array}{l}608 \\
580\end{array}$ \\
\hline $\mathrm{Hb}$. & $\begin{array}{l}1 \\
2\end{array}$ & $\begin{array}{l}6 \\
8\end{array}$ & $\begin{array}{l}70 \\
82\end{array}$ & $\begin{array}{l}55 \\
75\end{array}$ & $\begin{array}{l}58 \\
55\end{array}$ & $\begin{array}{l}51 \\
58\end{array}$ & $\begin{array}{l}50 \\
55\end{array}$ & $\begin{array}{l}50 \\
53\end{array}$ & $\begin{array}{l}45 \\
53\end{array}$ & $\begin{array}{l}44 \\
55\end{array}$ & $\begin{array}{l}59 \\
52\end{array}$ & 57 & $\begin{array}{l}72 \\
68\end{array}$ & $\begin{array}{l}81 \\
77\end{array}$ \\
\hline $\mathrm{H}$ & $\begin{array}{l}1 \\
2\end{array}$ & $\begin{array}{l}70 \\
85\end{array}$ & $\begin{array}{l}0.59 \\
0.86\end{array}$ & $\begin{array}{l}0.68 \\
0.92\end{array}$ & $\begin{array}{l}0.86 \\
0.83\end{array}$ & $\begin{array}{l}0.73 \\
0.85\end{array}$ & $\begin{array}{l}0.53 \\
0.88\end{array}$ & $\begin{array}{l}0.56 \\
1.09\end{array}$ & $\begin{array}{l}0.51 \\
0.92\end{array}$ & $\begin{array}{l}0.52 \\
0.91\end{array}$ & $\begin{array}{l}0.71 \\
0.77\end{array}$ & $\begin{array}{l}0.68 \\
0.82\end{array}$ & $\begin{array}{l}0.68 \\
0.70\end{array}$ & $\begin{array}{l}0.67 \\
0.66\end{array}$ \\
\hline $\begin{array}{l}\text { Blood } \\
\text { catalase }\end{array}$ & $\begin{array}{l}1 \\
2\end{array}$ & & $\begin{array}{l}5.10 \\
4.69\end{array}$ & $\begin{array}{l}4.86 \\
3.74\end{array}$ & $\begin{array}{l}3.91 \\
4.35\end{array}$ & $\begin{array}{l}3.91 \\
4.01\end{array}$ & $\begin{array}{l}4.93 \\
3.20\end{array}$ & $\begin{array}{l}5.81 \\
3.84\end{array}$ & $\begin{array}{l}4.25 \\
3.60\end{array}$ & $\begin{array}{l}4.01 \\
4.42\end{array}$ & $\begin{array}{l}4.79 \\
3.81\end{array}$ & $\begin{array}{l}4.79 \\
4.96\end{array}$ & $\begin{array}{l}7.14 \\
5.10\end{array}$ & $\begin{array}{l}6.09 \\
5.27\end{array}$ \\
\hline Plas & $\begin{array}{l}1 \\
2\end{array}$ & $\begin{array}{l}25.16 \\
26.52\end{array}$ & $\begin{array}{l}13.60 \\
10.20\end{array}$ & $\begin{array}{l}17.0 \\
12.2\end{array}$ & 29.2 & 13.60 & 5.4 & 34 & 2516 & & 40 & 4. & 0 & $\begin{array}{l}4.68 \\
5.84\end{array}$ \\
\hline $\begin{array}{l}\text { Cata } \\
\text { in }\end{array}$ & $\begin{array}{l}1 \\
2\end{array}$ & & $\begin{array}{l}.86 \\
.99\end{array}$ & $\begin{array}{l}1.19 \\
0.91\end{array}$ & $\begin{array}{l}1.16 \\
1.32\end{array}$ & $\begin{array}{l}1.12 \\
1.17\end{array}$ & $\begin{array}{l}1.05 \\
1.02\end{array}$ & $\begin{array}{l}1.31 \\
1.58\end{array}$ & $\begin{array}{l}0.96 \\
1.26\end{array}$ & $\begin{array}{l}0.96 \\
1.46\end{array}$ & $\begin{array}{l}1.14 \\
1.13\end{array}$ & $\begin{array}{l}1.00 \\
1.43\end{array}$ & $\begin{array}{l}1.33 \\
1.05\end{array}$ & $\begin{array}{l}1.00 \\
0.91\end{array}$ \\
\hline $\begin{array}{r}\mathrm{Hb-c} \\
\text { in }\end{array}$ & $\begin{array}{l}1 \\
2\end{array}$ & $\begin{array}{l}38 \\
48\end{array}$ & 0.43 & $\begin{array}{l}0.51 \\
0.29\end{array}$ & $\begin{array}{l}0.39 \\
0.46\end{array}$ & $\begin{array}{l}0.44 \\
0.40\end{array}$ & $\begin{array}{l}0.59 \\
0.34\end{array}$ & $\begin{array}{l}0.67 \\
0.42\end{array}$ & $\begin{array}{l}0.55 \\
0.40\end{array}$ & $\begin{array}{l}0.53 \\
0.46\end{array}$ & $\begin{array}{l}0.47 \\
0.43\end{array}$ & $\begin{array}{l}0.43 \\
0.51\end{array}$ & $\begin{array}{l}0.57 \\
0.44\end{array}$ & $\begin{array}{l}0.44 \\
0.40\end{array}$ \\
\hline $\begin{array}{l}\text { Plasma-blood } \\
\text { catalase ratio }\end{array}$ & 1 & 68 & $\begin{array}{l}2.67 \\
2.18\end{array}$ & $\begin{array}{l}3.49 \\
3.27\end{array}$ & $\begin{array}{l}7.47 \\
2.03\end{array}$ & $\begin{array}{l}3.47 \\
5.94\end{array}$ & $\begin{array}{l}1.11 \\
3.81\end{array}$ & $\begin{array}{l}4.03 \\
4.96\end{array}$ & $\begin{array}{l}5.91 \\
8.27\end{array}$ & $\begin{array}{l}2.88 \\
3.76\end{array}$ & $\begin{array}{l}2.12 \\
4.63\end{array}$ & $\begin{array}{l}0.99 \\
5.52\end{array}$ & $\begin{array}{l}4.29 \\
1.60\end{array}$ & $\begin{array}{l}5.71 \\
4.90\end{array}$ \\
\hline
\end{tabular}

catalase content decreased rapidly together with erythrocytes and hemoglobin, but their recovery differed as presented in Table II. On the contrary, the plasma catalase content increased immediately after phenylhydrazine as well as reflected image in the mirror, and returned to a normal extent very slowly after stopping the injection.

3. Anemia caused by saponin

When $1 \%$ saponin was intravenously injected in doses of $1 \mathrm{cc}$. per $\mathrm{kg}$. on the first day, $1.5 \mathrm{cc}$. on the second day and $2 \mathrm{cc}$. on the third day, the blood catalase content decreased in a slight degree in company with erythrocytes and hemoglobin, contrary to the markedly increased content of plasma catalase, and then the recovery of the blood catalase content and hemoglobin preceded that of erythrocytes (Table III).

4. Anemia caused by colloidal silver

The results presented in Table IV show that $1 \%$ colloidal silver used intravenously in doses of $2 \mathrm{cc}$. per $\mathrm{kg}$. for 20 days lowers little by little the blood catalase content, erythrocytes and hemoglobin, but the decrease of the blood catalase content takes place newly later after stopping the injection. In particular, it is notable that the plasma catalase content increases in the first stage, but decreases afterwards preceding that of the blood catalase.

5. Intoxication by sodium nitrite

When $0.5 \mathrm{cc}$. per $\mathrm{kg}$. of $10 \%$ sodium nitrite which produces methemo- 


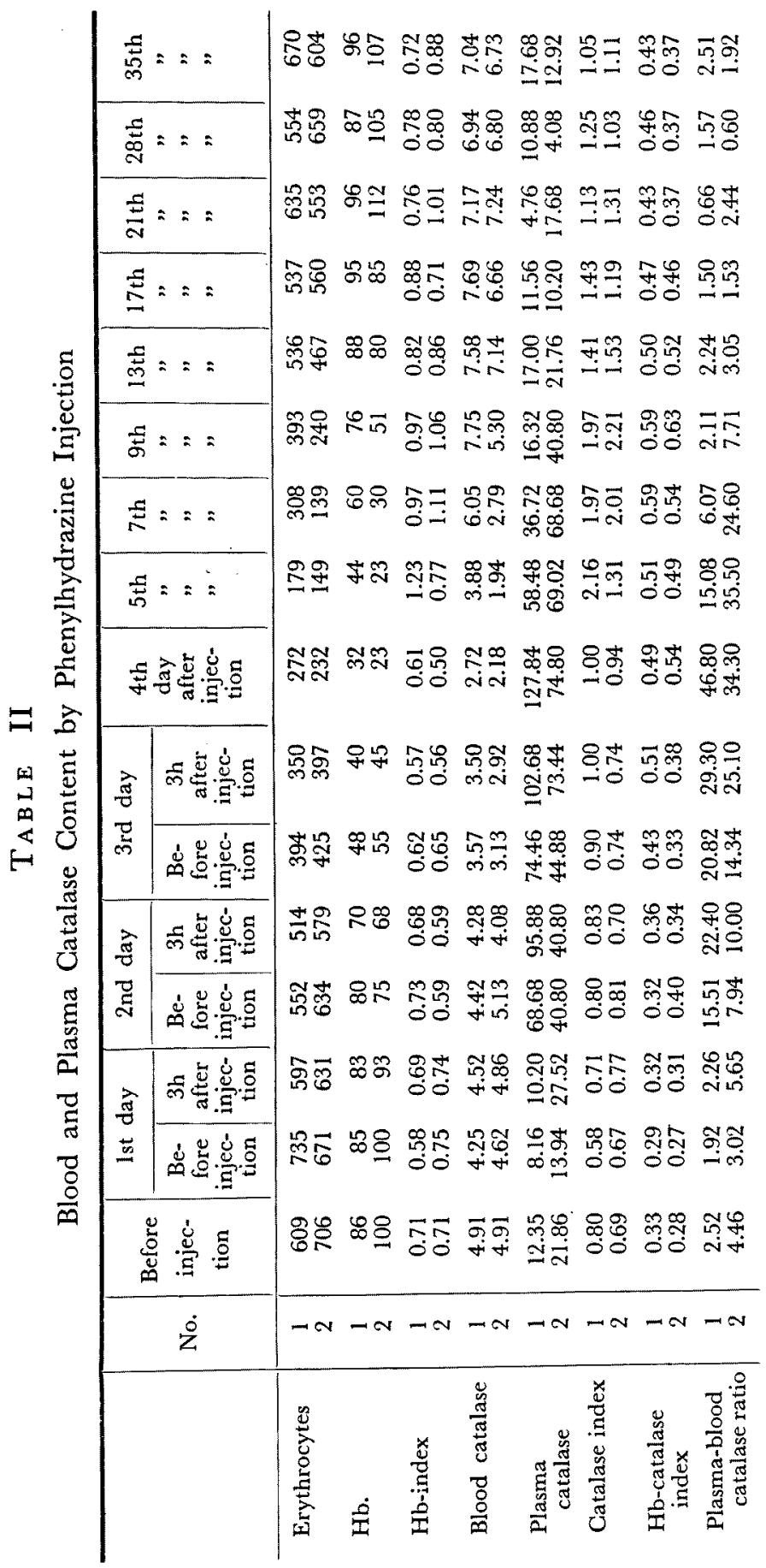




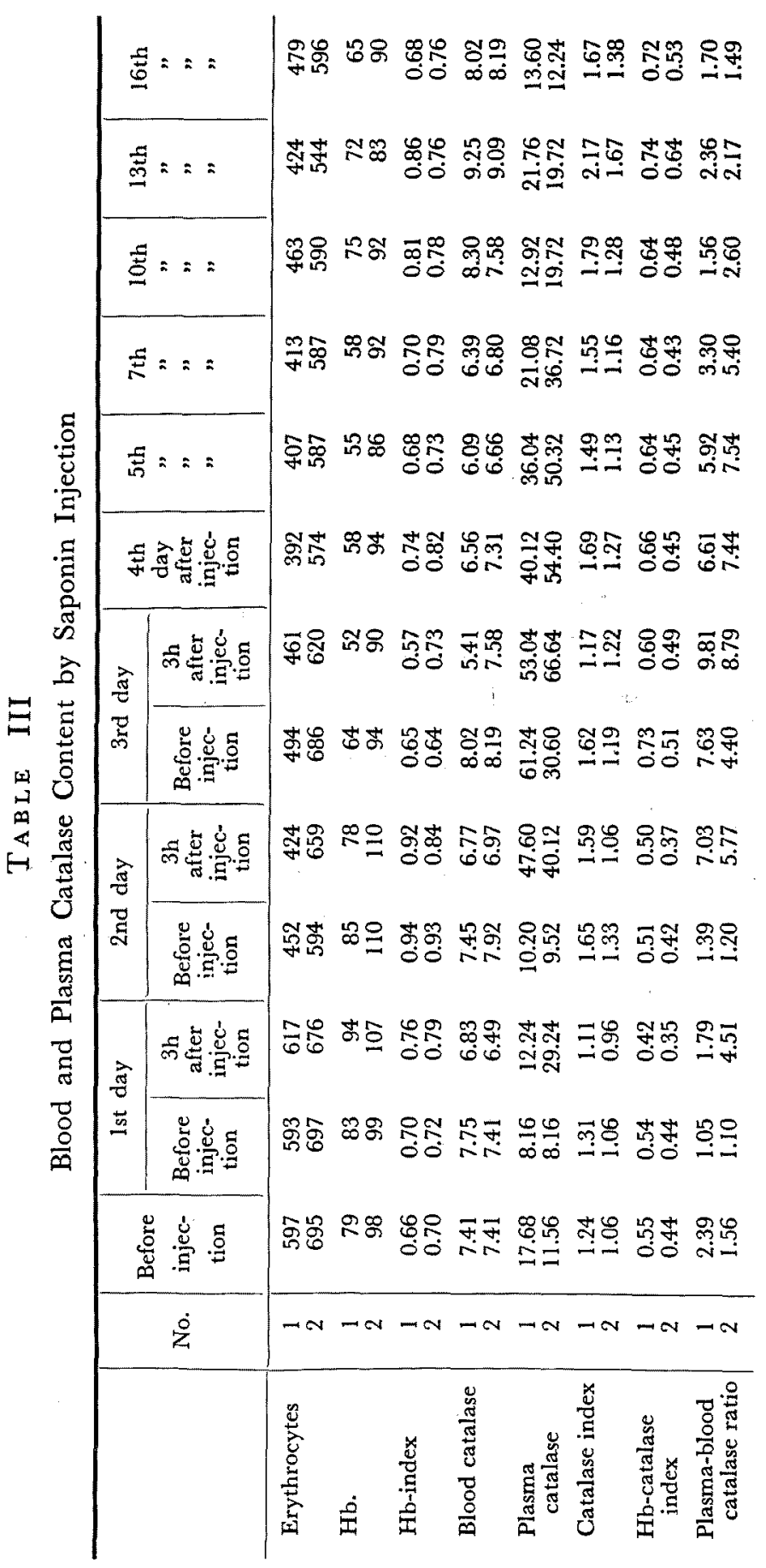


Blood and Plasma Catalase in Experimental Anemias

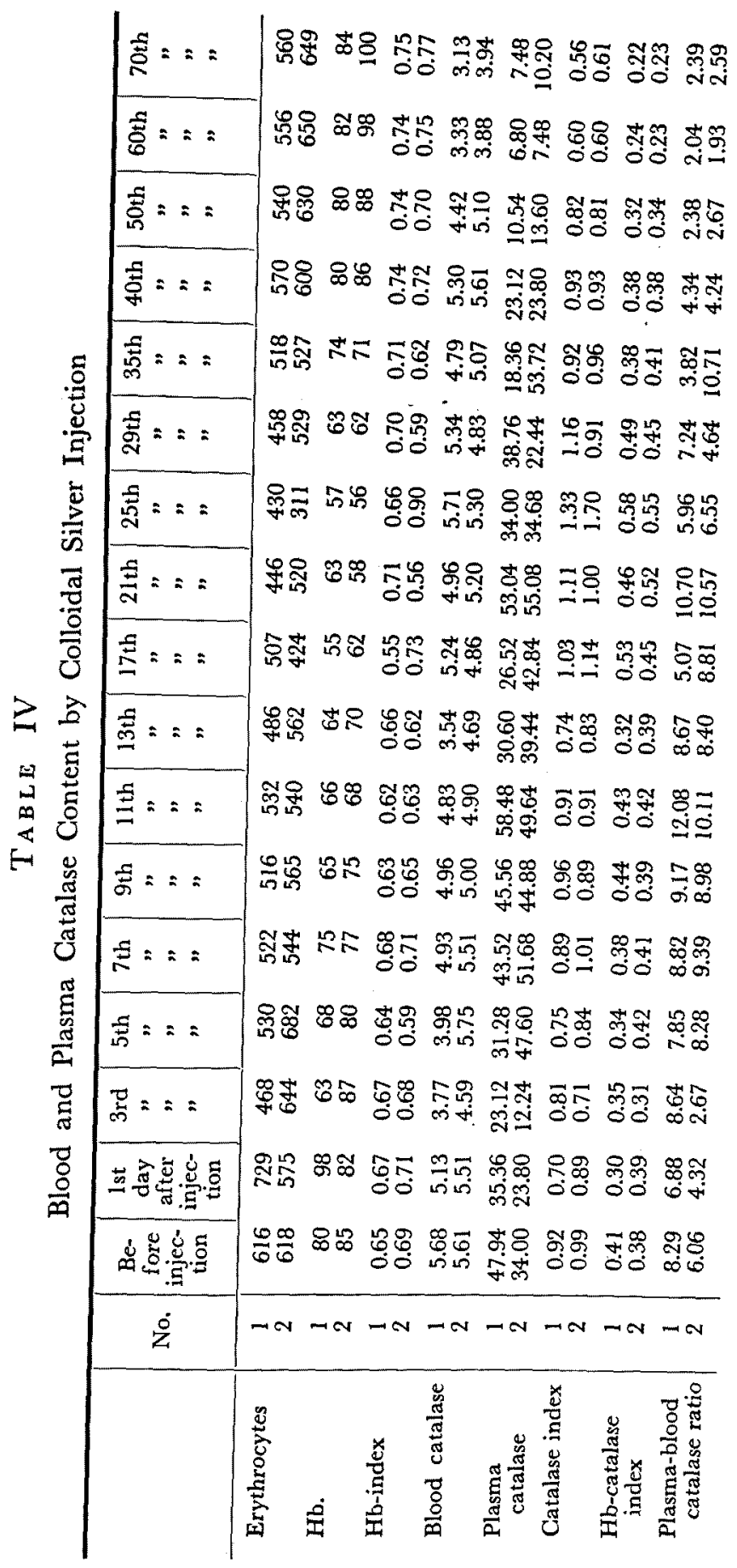


TABLE V

Blood and Plasma Catalase Content by Sodium

Nitrite Injection

\begin{tabular}{|c|c|c|c|c|c|c|c|c|c|}
\hline & \multirow{2}{*}{ No. } & \multirow{2}{*}{$\begin{array}{c}\text { Before } \\
\text { injec- } \\
\text { tion }\end{array}$} & \multicolumn{7}{|c|}{ After injection (time in hours) } \\
\hline & & & 0.25 & 0.5 & 1 & 2 & 3 & 5 & 7 \\
\hline Erythrocytes & $\begin{array}{l}1 \\
2\end{array}$ & $\begin{array}{l}617 \\
621\end{array}$ & $\begin{array}{l}575 \\
618\end{array}$ & $\begin{array}{l}614 \\
623\end{array}$ & $\begin{array}{l}599 \\
598\end{array}$ & $\begin{array}{l}617 \\
624\end{array}$ & $\begin{array}{l}577 \\
608\end{array}$ & $\begin{array}{l}629 \\
628\end{array}$ & $\begin{array}{l}615 \\
619\end{array}$ \\
\hline $\mathrm{Hb}$. & $\begin{array}{l}1 \\
2\end{array}$ & $\begin{array}{l}97 \\
90\end{array}$ & $\begin{array}{l}92 \\
90\end{array}$ & $\begin{array}{r}101 \\
91\end{array}$ & $\begin{array}{r}104 \\
95\end{array}$ & $\begin{array}{r}102 \\
98\end{array}$ & $\begin{array}{l}95 \\
92\end{array}$ & $\begin{array}{l}102 \\
101\end{array}$ & $\begin{array}{l}94 \\
91\end{array}$ \\
\hline Hb-index & $\begin{array}{l}1 \\
2\end{array}$ & $\begin{array}{l}0.78 \\
0.73\end{array}$ & $\begin{array}{l}0.80 \\
0.73\end{array}$ & $\begin{array}{l}0.82 \\
0.73\end{array}$ & $\begin{array}{l}0.87 \\
0.79\end{array}$ & $\begin{array}{l}0.83 \\
0.79\end{array}$ & $\begin{array}{l}0.82 \\
0.75\end{array}$ & $\begin{array}{l}0.81 \\
0.80\end{array}$ & $\begin{array}{l}0.76 \\
0.74\end{array}$ \\
\hline Blood catalase & $\begin{array}{l}1 \\
2\end{array}$ & $\begin{array}{l}8.87 \\
8.02\end{array}$ & $\begin{array}{l}8.84 \\
8.19\end{array}$ & $\begin{array}{l}8.53 \\
7.75\end{array}$ & $\begin{array}{l}7.75 \\
7.58\end{array}$ & $\begin{array}{l}7.99 \\
8.30\end{array}$ & $\begin{array}{l}8.60 \\
7.96\end{array}$ & $\begin{array}{l}8.06 \\
7.75\end{array}$ & $\begin{array}{l}7.99 \\
7.99\end{array}$ \\
\hline $\begin{array}{l}\text { Plasma } \\
\text { catalase }\end{array}$ & $\begin{array}{l}1 \\
2\end{array}$ & $\begin{array}{l}27.88 \\
13.60\end{array}$ & $\begin{array}{l}19.04 \\
12.24\end{array}$ & $\begin{array}{l}19.38 \\
12.58\end{array}$ & $\begin{array}{l}23.80 \\
17.68\end{array}$ & $\begin{array}{l}18.36 \\
11.56\end{array}$ & $\begin{array}{l}23.12 \\
14.62\end{array}$ & $\begin{array}{l}20.74 \\
12.92\end{array}$ & $\begin{array}{l}18.02 \\
11.22\end{array}$ \\
\hline Catalase index & $\begin{array}{l}1 \\
2\end{array}$ & $\begin{array}{l}1.44 \\
1.29\end{array}$ & $\begin{array}{l}1.54 \\
1.32\end{array}$ & $\begin{array}{r}1.38 \\
\quad 1.24\end{array}$ & $\begin{array}{l}1.29 \\
1.27\end{array}$ & $\begin{array}{l}1.29 \\
1.32\end{array}$ & $\begin{array}{l}1.47 \\
1.30\end{array}$ & $\begin{array}{l}1.28 \\
1.23\end{array}$ & $\begin{array}{l}1.30 \\
1.29\end{array}$ \\
\hline $\begin{array}{l}\text { Hb-catalase } \\
\text { index }\end{array}$ & $\begin{array}{l}1 \\
2\end{array}$ & $\begin{array}{l}0.53 \\
0.52\end{array}$ & $\begin{array}{l}0.56 \\
0.53\end{array}$ & $\begin{array}{l}0.49 \\
0.49\end{array}$ & $\begin{array}{l}0.43 \\
0.47\end{array}$ & $\begin{array}{l}0.46 \\
0.49\end{array}$ & $\begin{array}{l}0.52 \\
0.50\end{array}$ & $\begin{array}{l}0.46 \\
0.45\end{array}$ & $\begin{array}{l}0.49 \\
0.51\end{array}$ \\
\hline $\begin{array}{l}\text { Plasma-blood } \\
\text { catalase ratio }\end{array}$ & $\begin{array}{l}1 \\
2\end{array}$ & $\begin{array}{l}3.14 \\
1.70\end{array}$ & $\begin{array}{l}2.16 \\
1.40\end{array}$ & $\begin{array}{l}2.27 \\
1.62\end{array}$ & $\begin{array}{l}3.07 \\
2.33\end{array}$ & $\begin{array}{l}2.30 \\
1.39\end{array}$ & $\begin{array}{l}2.69 \\
1.84\end{array}$ & $\begin{array}{l}2.57 \\
1.67\end{array}$ & $\begin{array}{l}2.25 \\
1.40\end{array}$ \\
\hline
\end{tabular}

globin in the blood, was intravenously injected, the change of the blood and plasma catalase content, erythrocytes and hemoglobin remained almost within a physiological variation (Table V).

\section{Discussion}

It is generally accepted that the blood catalase content decreases in parallel with erythrocytes and hemoglobin in anemia caused by artificial bleeding (Bernstein ${ }^{3)}$, Ochi' ${ }^{4}$, Nozaki ${ }^{5}$, Takimoto and $\mathrm{Kubo}^{6}$ ), Bode ${ }^{7}$, v. Krüger ${ }^{8)}$, Fujikawa ${ }^{9)}$ ), but Kurokawa ${ }^{10)}$ and Takisawa ${ }^{11}$ recognize the plasma catalase content to be unchangeable. As for the catalase index of the above-stated anemia, Nozaki ${ }^{5)}$, Takimoto ${ }^{6)}$ and Fujikawa ${ }^{9)}$ recognize the temporary increase, but Bode ${ }^{7)}, \mathrm{Nissen}^{12)}$, Bernstein ${ }^{3)}$, Ochi ${ }^{4}$ and v. Krüger $^{8)}$ report it to be constant. The results obtained from our experiments show that the blood catalase content decreases in company with erythrocytes and hemoglobin, but the recovery of the former precedes that of erythrocytes and hemoglobin. Therefore, the catalase index, hemoglobin-catalase index and plasma-blood catalase ratio tend to increase temporarily, while the plasma catalase content is not so variable.

In anemia cuased by phenylhydrazine which is compared to pernicious anemia, many workers, such as Nissen ${ }^{12)}$, Bernstein ${ }^{3)}$, Ochi $^{4)}$, Nozaki' ${ }^{51}$, Takimoto and $\mathrm{Kubo}^{6)}$, v. Krüger ${ }^{8}$ ) and Fujikawa ${ }^{9)}$, recognize that the catalase index increases remarkably. Data presented in our experiments 
show that the decrease of the blood catalase content precedes that of erythrocytes and hemoglobin and the increase of the plasma catalase content evidently continues for more than one week after the last injection. Therefore, the catalase index, hemoglobin-catalase index and plasma-blood catalase ratio increase remarkably, but the latter subsequently decreases to the subnormal degree.

Gaisböck and Bayer ${ }^{13)}$ as well as $\mathrm{Kano}^{14)}$ report that saponin, the hemolytic toxin, is accompanied by the disturbed function of the bone marrow. According to our results, it is presumed that the plasma catalase is produced by hemolysis in a living body, because it changes as reflected image in the mirror, compared with the blood catalase. Moreover, in the above-stated anemia as well as anemia caused by phenylhydrazine, the recovery of the blood catalase and hemoglobin is more marked than that of erythrocytes, therefore, it is accompanied by the excitement of the hemopoietic function.

As to the blood and plasma catalase of anemia caused by colloidal silver which is compared to aplastic anemia by Komiya ${ }^{15}$, there is no report. Our results show that the decrease of the blood and plasma catalase content is still remarkable after the stopping of the injection, especially, the latter is more marked than the former.

Furthermore, we attempted to estimate the influence of the intoxication by sodium nitrite, which is recognized as a toxin to cause methemoglobin by Loewy ${ }^{16)}$. Our results show that the variation of the blood and plasma catalase content remains almost within a physiological change, and then the catalytic power of the blood and plasma can not be identified with hemoglobin.

Therefore, it is presumed that the variation of the blood and plasma catalase content in various experimental anemias is produced by functional or anatomical disorders of the hemopoietic organs.

\section{SUMMARY}

From these experiments with various experimental anemias caused by artificial bleeding, phenylhydrazine, saponin, colloidal silver and sodium nitrite, it can be concluded that the blood and plasma catalase is produced in the hemopoietic organs by different process from that of erythrocytes and hemoglobin, while a larger portion of the plasma catalase is produced by the hemolysis in a living body.

\section{References}

1) Yamagata and Seino, Tohoku J. Exp. Med., 1952, 57, 101.

2) Yamagata, Seino and Nakao, ibid., 1952, 57, 85.

3) Bernstein, Biochem. Z., 1926, 179, 304. 
4) Ochi, Hokkaido Med. J. (Jap.), 1928, 6, 693.

5) Nozaki, J. Chôsen Med. Assoc. (Jap.), 1929, 19, 1319.

6) Takimoto and Kubo, J. Gastroenterology (Jap.), 1930, 5, 868.

7) Bode, Z. exp. Med., 1931, 77, 558.

8) v. Krüger, ibid., 1933, 88, 437.

9) Fujikawa, Mitt. d. med. Ges. zu Okayama (Jap.), 1935, 47, 3072.

10) Kurokawa, Tohoku .J. Exp. Med., 1930, 14, 520.

11) Takisawa, ibid., 1931, 18, 223.

12) Nissen, Z. klin. Med., 1921, 92, 1.

13) Gaisböck and Bayer, Wien. klin. Wschr., 1924, 952.

14) Kano, Mitt. d. Med. Ges. zu Nagoya (Jap.), 1934, 41, 695.

15) Komiya et al., J. Kumamoto Med. Soc. (Jap.), 1928, 4, 121.

16) Loewy, Zbl. f.d. ges. inn. Med. u. Grenzgeb., 1937, 88, 374. 